\title{
Disputes on Public Roads: Coal Transportation Policy and Actor Networks in Jambi Province,
} Indonesia

\author{
Ahmad Subhan \\ Governmental Science, Padjadjaran University, Indonesia \\ ahmadsoebhan01@yahoo.com
}

\begin{abstract}
Besides providing financial contributions to local revenue, coal also increases transportation problems in Jambi province. Mobilization of trucks that pass through the public roads has caused damage although already a regional policy that forbids it. This phenomenon has brought some disputes implication among local stakeholders in various forms, either in the judiciary or in the field. This paper examines that phenomenon from public policy aspects, especially from a policy actor networks perspective. This study used a descriptive qualitative approach by relying on documentary data which revealed that the complexity of coal transportation issues in Jambi province is visible from regulation violations by coal entrepreneurs that use the public road. Demonstrations by coal truck driver, road blockage protests by resident and even efforts by coal entrepreneurs are held to revise local regulation. The source of the problem is due to self-interests of government officials and coal operators. The key solution is law enforcement and policy support from district government towards the provincial government policies.
\end{abstract}

Keywords: Public policy, actor-network, policy network, coal transportation, Jambi Province

\section{Introduction}

The existence of abundant natural resources in a region is not only a source of local revenue but also requires deep attention to environmental aspects, good governance, and sustainable development. Synergy and harmonization between all stakeholders who are involved in resource utilization are the keywords to adjust productivity, including coal resources. Coal is a major contributor to the state revenue where Jambi province is one of the centers of production. According to the Ministry of Energy, Jambi province has potentially as much as 788.65 million tons of coal scattered in several districts: Bungo, Tebo, Tanjabbarat, Sarolangun, Merangin, Batanghari and Muaro Jambi. Coal is the main mining materials in Jambi, in addition to oil and gas. Coal production from 2007 until May 2012 reached 21.7 million metric tons (ESDM, 2004). If calculated by the standard price of coal, USD 112/ton, the coal sales from Jambi reached USD 1, 7 billion. Behind the financial contributions to the local revenue, coal also poses complex problems in Jambi province, especially transportation from the mine location to stockpile. Hundreds of coal trucks moving from mining areas in some districts which are mostly located in the western area to the port in the eastern area of Jambi province. The mobilization of trucks using public road has caused road damage. The roads condition with carrying capacity of 8 tons is not able to withstand the coal trucks weighing up to ten tons or more.

The problem of road damage as a result of coal transportation has been going on since 2009. At least there are some impacts that arise:

a. Public roads become damaged due to overloaded trucks and not in accordance with the classification of existing roads in Jambi.

b. Financial losses because local governments have to spend substantial funds to improve the road condition

c. There was a lot of traffic accidents are caused by road hollow

d. Some house foundation fell a few meters because the coal truck exceeds the capacity.

In response, on 28 $8^{\text {th }}$ December2012, Regional Regulation (Perda) of Jambi Province Number 13 of 2012 was approved regarding the coal transportation in Jambi Province. This regulation sets any coal transport in Jambi province. They are required thoroughfares on special roads or rivers. The special road should be built and ready to use no later than January 2014. This policy showed a one-year grace period to businessmen to create their own special roads to transport the coal. Seen here, the government has accommodated the needs of the business community by providing options for businesses to prepare special road and not use public roads. This step was taken as a mutual agreement between the government and businesses in the phase of the regional regulation formulation. For additional regulation, Jambi provincial government in March 2013 
issued a Governor Regulation Number 18 of 2013 on Procedures for the Implementation of Coal Transportation in which has established Integrated Team (Timdu) to provide guidance, supervision and law enforcement. The team consists of representatives from several authorities (Department of Transportation, Department of Energy, Army, Police, Police Civil Service and other related elements). Any party which violates the provisions through public roads will be subject to administrative sanction as revocation of the mining license.

The one-year deadline had passed, and a special road has not been realized. Likewise, rivers are difficult to use because of silting. Negotiations with foreign investors about dredging of Batang Hari River was carried out since 2010 but failed. The consequences that emerge later are coal transport activity still use public roads. It increased the coal transportation problem in Jambi province. Since January 2014, Timdu (Tim Terpadu/Integrated Team) has conducted surveillance and made prosecution for violations by the coal transportation companies. This raised resistance from coal entrepreneurs who insiston remaining able to pass via a public road. They still operate trucks on public roads although it was banned. On the other hand, businessmen also threatened to review Governor Regulation on the coal transportation by referring it to the administrative court. They assume that the policy arbitrarily, to the detriment of employers and violate higher regulations, namely Act Number 22/2009 on National Road Traffic which is not a regional authority to regulate it (Jambi Independent, 20/1/2014). Resistance from entrepreneurs is also made clear by moving on mass coal truck driver to demonstrate at the Governor's Office in Jambi. They are not just single protest by the drivers, but they take their trucks to the Governor's Office in Jambi (Jambi Independent, 15/1/2014)). In addition, coal drivers also take action blocking the Sumatra highway as part of a protest.

Coal entrepreneurs have a bargaining power that allows them to resist government policies. Coal contributions to the regional income are significant where provisions are in place which results in 80 percent to be for regions and 20 percent of the national government income. In 2010, Jambi province income reaches USD 4 million per year from coal (Dinas ESDM, 2011). Although there is resistance from businessmen, provincial governments are still providing the provisions of Perda (Provincial Regulation) and Pergub (Governor Regulation). The Jambi Governor said that the implementation of the policy was not negotiable because sufficient time was provided to adjust (Jambi Independent, 20/1/2014). The situation becomes more problematic when citizens begin to react with a blockade of the road. This action has occurred repeatedly in several villages located on the side of the road. Residents react as caused by inconvenience, such as public road damage that endangers the safety of citizens. One of the roads blocking action by citizen occurred on March 11, 2014, at Lingkar Selatan Kebun Bohok (Jambi Independent, 12/3/2014). It is important to note that the provincial government's policy cannot be separated from the district/city because in Perda was regulated that the regents (Bupati) and mayors (Walikota) have to set the transport lines that allowed coal transportation to pass through. In other words, the provincial government policy also requires the support of district policy, and the policy also concerns with the intergovernmental relationship. Several district/city related to the transport of coal, among others are: Tebo, Bungo, Sarolangun, Merangin, Batanghari, Muaro Jambi, Tanjabbarat, and Jambi. Two districts, Tebo and Bungo, have set coal transport companies that are allowed to operate.

Empirical evidence described above showed a fairly complex policy issues where government policy is not fully understood and obeyed by coal entrepreneurs and has caused a negative impact on public interest, particularly public road damage. This brief article is to examine that issue from public policy aspects in the context of regional autonomy, especially policy network approach. This policy case is important to be explored more deeply with the policy actor networks perspective for several reasons: first, this phenomenon does not only happen in Jambi province but also has the potential to occur in other coal producers such as South Sumatra, West Sumatra, Riau, Bengkulu, East Kalimantan, South Kalimantan and Central Kalimantan. Secondly, the involvement of many actors with their respective interests will be considered in the networking approach. Third, the study of the dynamics of local government policy will be complete and adequate by policy network approach when coincided with the demands of democratization and good governance. 


\section{Literature Review}

Discussion on coal transportation modes in several areas in Indonesia led to the fact that they still use the conventional way with trucking. This distribution means, of course, is still lagging far from other countries who also manage coal mainly Western countries in Americas. As pointed out by Morrison (1985) the use of trains for coal transportation in the United States increased along with the extensive reach of railroads. Furthermore, Satar \& People (2010) said that coal transportation in the US achieved allocation efficiency when shippers have access to all major transportation modes. In contrast, the condition for allocative efficiency is not met with respect to market prices when shipper's modal choices are limited to trucking and rail service. More in-depth, Kozan (2012) has done research about integrated coal transportation. The results showed that the integrated train-stockpile-ship timetable is important to be created and optimized for improving the overall efficiency of coal transport system.

Associated with the exploration of coal in Jambi province, look much different because it still uses a single coal delivery way: trucking. In the conditions of there is no railway, coal transportation in Jambi with trucks pose complex problems as expressed before in the background section. The complexity can be seen from the aspect of the actors involved, the pattern of relationships, interaction strategies, interests, and resources of each. Such characteristics are conceptual can be studied with policy network concept. Policy networks focused on analyzing the public policy process is based on the idea of resource distribution and interdependencies, in organizational features and inter-organizational relationship. According to Kickert et al. (1997), the policy network examines patterns of social relationships between several actors who have a dependency to one another when they play a role in the public policy process. Meanwhile, according to Enroth (2011), the policy network has characteristics such as interdependencies, resources exchange, coordination, and plurality. Thus, policy networks see the policy as a process that is contextual where there is a complexity of relationships between the various actors, both formal and informal, with the own goals that has a dependency to one another.

The actors experiencing problem uncertainty caused by a lack of knowledge and information with unpredictable individual behavior, as well as the institutional context within the scope of the social environment (March and Olson, 1989). According to Klijn and Koppenjan (2016), there are three forms of the problem of uncertainty in the interaction between actors, among others substantive, institutional and strategic. An actor can not necessarily identify policy issues only with the information obtained by ownself, but it also requires information from other sources or from other actors. Differences in the interpretation of information also often make a worse situation between actors due to different references. The network problems should be clearer and the same meaning by all actors, so they can formulate some solutions that are more precise and comprehensive.

The actors in the coal transportation policy come from different institutional backgrounds. As a result, they not only have different perceptions, strategies, and interests, but also organizational and administrative levels are not the same. Fragmentation within the scope of institutional means the important decisions taken by some players in the policy arena, sometimes even elitist. So the network manager needs to encourage participation from various actors in policy networks, both formally and informally. The strategic uncertainty is closely connected with the actor's strategic choices in an effort to articulate its objectives and problem solutions (Ostrom, 1990). Interaction among actors in the decision-making process with different perception and own solution makes the network be more complex and the policy implementation process does not give the expected results.

\section{Methodology}

This paper used the descriptive method with a qualitative approach that relies on secondary data obtained from the documents of legislation and news archives from local mass media. Basic parameters in the analysis based on identification of the parties that involved and action that they have done. Secondary data collection is done in a period of April 2014 until April 2015. The validity of the data is guaranteed by the triangulation of data sources and methods. Data analysis used qualitative analysis in which data obtained will be classified, reduced, categorized, mapped and interpreted to make a conclusion based on policy network perspective. 


\section{Results and Discussion}

Policy Description: Coal transportation policy detailed in Jambi Provincial Regulation (Perda) No. 13/2012 concerning Coal Transportation Activity in Jambi Province. This regulation should be carried out in order to develop harmonization between stakeholders with the following objectives:

a. Realize the security, public order and the safety of road users;

b. Realize the road network system that is efficient and effective for the sake of the implementation of an integrated transport system;

c. Realize the coal transportation line through the river;

d. Encourage efforts to accelerate social and economic development, and

e. Encourage and provide support to the private sector to build a special road.

This regulation confirms that every coal trucks obligated to passing through special road or river line. The special road should be ready no later than January 2014, but if it has not been built or yet to be used, the transport of coal via public roads arranged by the Regional Head in accordance with its authority. About the river, if it is not adequate for the transport of coal, it can be done through public roads that arranged by the Regional Head in accordance with its authority. The certainly public road is the road that connects the shortest distance from the mine site to the stockpile in the nearest river from the mine site. Regions of coal production in Jambi province including Bungo, Sarolangun, Merangin, Tebo, Batanghari, Muaro Jambi and Tanjab Barat. The road that has been traversed by a coal truck is divided into two areas, among others: area 1 from Bungo, Tebo, and Tanjab Barat via Lubuk Kambing. This area is relatively not passed through public road because there is a special track. Area 2 from Merangin, Sarolangun, Batanghari and Muaro Jambi via public road to the Talang Duku Port often passes through Jambi city. This area is a problem source because there is no special line so that coal trucks are still crossing the public road. Thus, local governments that related to Area 1 including Bungo, Tebo, and Tanjab Barat. The local governments that associated with Area 2 consist of Merangin, Sarolangun, Batanghari, Muaro Jambi, and Jambi City.

Figure 1: Map of Coal Transportation in Jambi Province

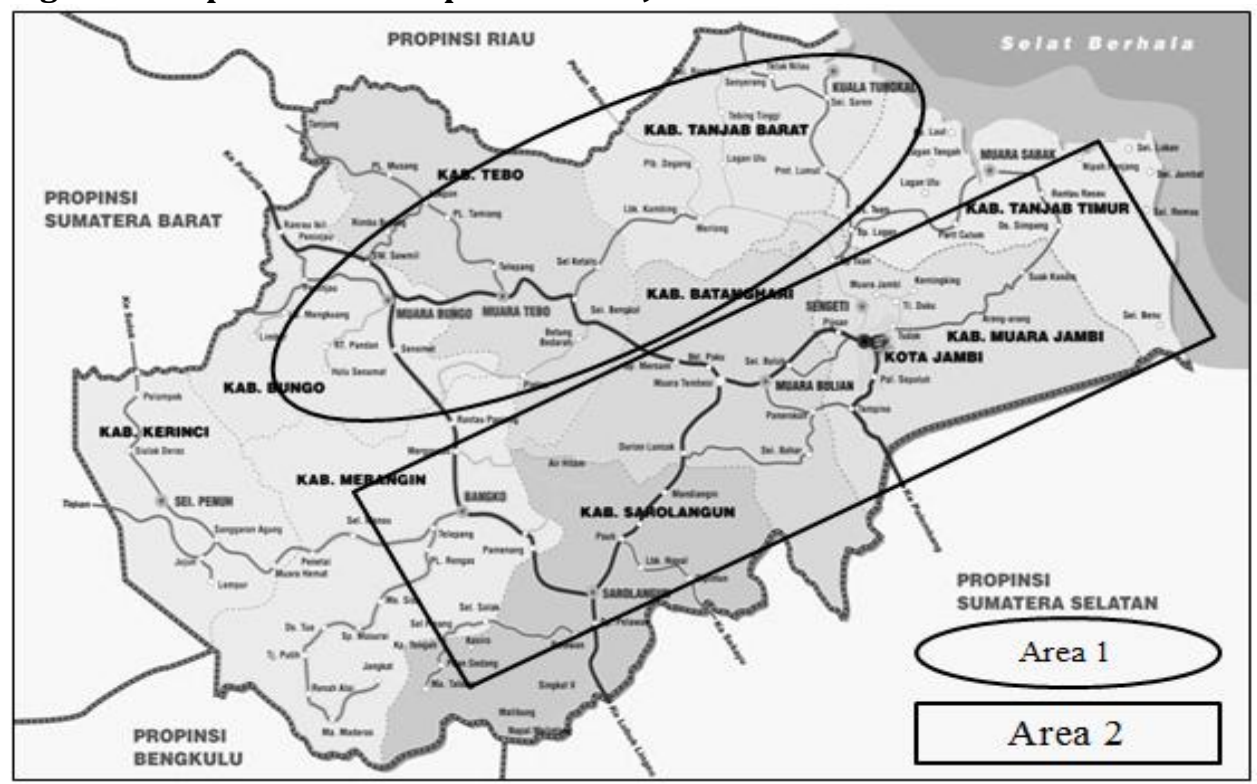

Specifically for the transport of coal from the mine in Bungo and Tebo district can through certain public roads as follows:

- From Bungo district through Jalan Muara Bungo-Tebo towards road Simpang Lubuk Niam-Lubuk Kambing-Merlung-the Port of Taman Rajo at Tungkal Ulu Tanjabbar. 
- From Tebo district, leading to the Simpang Lubuk Niam-Lubuk Kambing-Merlung-the Port of Taman Rajo at Tungkal Ulu Tanjabbar.

- Specifically, transportation from the coal mine to the West Sumatra region can pass through a public road by following the rules in force.

Meanwhile, transportation from the coal mine site in District of Merangin, Sarolangun, Batang Hari and Muaro Jambi through the river in the each district towards the coal port terminal to be transported out of Jambi province. Coal transportation from the mine to the coal stockpiles may use public roads specified by Bupati as appropriate authority. Any coal company that violates these guidelines may be subject to administrative sanctions such as:

a. Warning letter;

b. Cutting of production target that proposed for the following year

c. Revocation of mining permits including:

- Revocation of the mining license for production.

- Revocation of the operating license of transport and sales.

- Revocation of the business license of mining transportation services.

This arrangement reinforced by Pergub Number 18/2013 regarding Procedures of Coal Transportation. This regulation provides guidance on the implementation of coal transportation through public road and river channel as well as providing opportunities for coal mining business activities can continue to be implemented. In addition, Pergub also reinforces the role of local government to provide guidance, regulation, surveillance, control and enforcement of the transport of coal to be run in accordance with applicable regulations through the establishment of the Integrated Team (Tim Terpadu) consisting of representatives from Department of Transportation, Department of Energy, Army, Police, Satpol PP and other related elements.

Mapping Actors Based on Resources, Interests, and Strategy: Coal transportation policy in Jambi province can be seen as a policy process that involves many actors with their respective interests where they have the resources and strategies to interact. Hence, policy network analysis can be done by mapping the resources, interests, and strategies of each actor involved in policy. Relationship pattern that occurs during the policy interaction is also necessary so that policy analysis with networking approach more clearly and comprehensively. More simply, the complexity of the coal transportation policy network in Jambi province can be seen in the following table:

Table 1: Complexity of Coal Transportation in Jambi Province from Resources, Interests, and Strategy

\begin{tabular}{|c|c|c|c|}
\hline Actor & Resources & Interests & Strategy \\
\hline $\begin{array}{l}\text { Provincial } \\
\text { Government }\end{array}$ & $\begin{array}{l}\text { Regulations authority } \\
\text { Central government } \\
\text { representative in the } \\
\text { regions } \\
\text { Inter-regional } \\
\text { authority road }\end{array}$ & $\begin{array}{l}\text { The public roads are not } \\
\text { damaged by } \\
\text { transportation } \\
\text { Local Revenue from coal } \\
\text { Public legitimacy }\end{array}$ & $\begin{array}{l}\text { Enforce coal transportation } \\
\text { regulations } \\
\text { Pergub) } \\
\text { Provide a deadline for coal } \\
\text { businessmen to build a } \\
\text { special road }\end{array}$ \\
\hline $\begin{array}{l}\text { District } \\
\text { Government }\end{array}$ & $\begin{array}{l}\text { Regulations authority } \\
\text { Road Authority }\end{array}$ & $\begin{array}{l}\text { The public roads are not } \\
\text { damaged by coal } \\
\text { transportation } \\
\text { Local revenue from coal } \\
\text { Public legitimacy }\end{array}$ & $\begin{array}{l}\text { Already formulated or yet } \\
\text { formulates Perbup that } \\
\text { concerning on } \\
\text { transportation }\end{array}$ \\
\hline $\begin{array}{l}\text { Coal } \\
\text { Businessmen }\end{array}$ & $\begin{array}{l}\text { Contribution } \\
\text { revenue } \\
\text { Supporting } \\
\text { activity }\end{array}$ & $\begin{array}{l}\text { Distribution becomes more } \\
\text { efficient } \\
\text { Reluctant to loss of profit } \\
\text { Closer distance } \\
\text { Allowed to pass through } \\
\text { public road }\end{array}$ & $\begin{array}{l}\text { Threatening to file a judicial } \\
\text { review of Perda and Pergub } \\
\text { to the court } \\
\text { Adhering to the business } \\
\text { license }\end{array}$ \\
\hline Integrated & Supervision authority & Carry & g measures to violation \\
\hline
\end{tabular}




\begin{tabular}{|c|c|c|c|}
\hline Actor & Resources & Interests & Strategy \\
\hline Team & Surveillance & monitoring enforcement & \\
\hline $\begin{array}{ll}\text { Coal } & \text { Truck } \\
\text { Driver } & \end{array}$ & $\begin{array}{l}\text { Being operators for coal } \\
\text { transportation activity }\end{array}$ & $\begin{array}{l}\text { Travel route to be closer } \\
\text { Demands of work }\end{array}$ & $\begin{array}{l}\text { Held demonstration in the } \\
\text { road } \\
\text { Blocking inter-regional road }\end{array}$ \\
\hline Local resident & Support and demand & $\begin{array}{l}\text { Public road not to be } \\
\text { damaged } \\
\text { There is no traffic jam } \\
\text { There is no interference from } \\
\text { coal trucks }\end{array}$ & $\begin{array}{l}\text { Blocking inter-regional road } \\
\text { Acted to road blockades } \\
\text { Demands to the provincial } \\
\text { government in order to law } \\
\text { enforcement }\end{array}$ \\
\hline
\end{tabular}

The complexity of coal transport policy in Jambi province can be parsed in table1 which clarify what resources and interests from each actor with how the strategy undertaken in the process of policy interactions. From the mapping, there are some things that need to be underlined: first, coal transportation policy is a policy that is closely linked to the public interest, especially the sustainability of public facilities of road infrastructure. The success or failure of the implementation of this policy will have an impact on public legitimacy for local government. Second, the local government has been negotiating with businessmen and giving tolerance time to build a special road for coal transportation, but it can not be realized. It showed still has not established common interests between local government and businesses. Regional government put the public interests in accordance to realize vision and mission, while businesses uphold calculative economic interests of profit and loss. Third, basically, truck driver are at a disadvantage because it only becomes a businessmen instrument to resistance against the policies by mobilizing demonstrations. In the field, the driver faced with Timdu as a watchdog implementation of regulation and also dealing with the citizens who protested by road blockade. In these circumstances, the driver in a position wedged in the middle, between elite and mass.

Mapping Relationship between Policy Actors: The mapping of resources, interests, and strategies that have been done before, will be more comprehensive if it is equipped with mapping the relationships among the actors involved in the coal transportation policy.

Figure 2: Pattern of interaction between actors in coal transportation policy

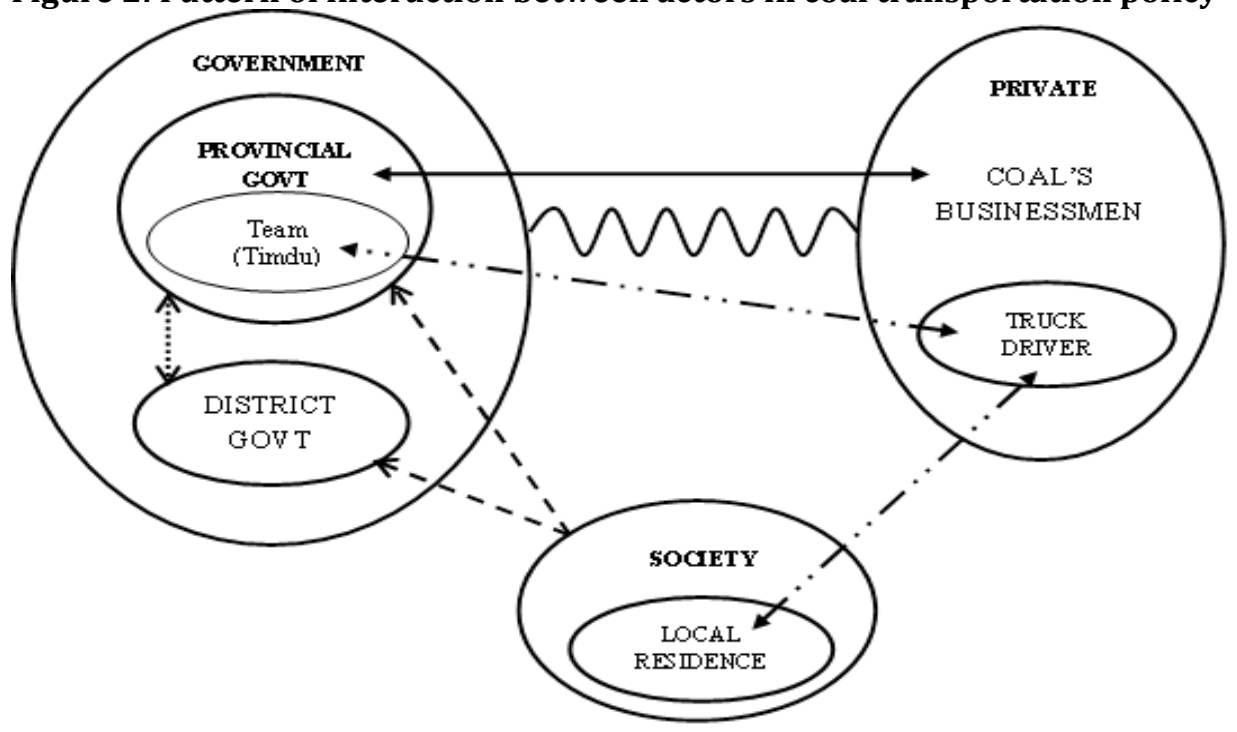

Caption:

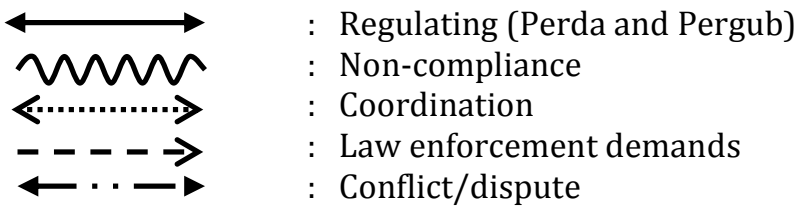


Figure 2 helps us determine the pattern of interaction between the stakeholders of the coal transportation policy in Jambi province. At least there are some points from mapping results, among others:

- In the implementation of Perda and Pergub, Jambi provincial government requires coordination and regulation from district government that determine which roads may be used by coal trucks.

- Coal truck drivers have been used by his boss as a tool for non-compliance and resistance action to local government policy.

- Disputes are visible on the surface would occur at two levels, namely between Timdu with drivers; and between citizens with drivers.

- The source of the problem is the difference in views and interests between local governments and coal businesses.

Policy issues that have occurred can be parsed after the main point to know where the relationship actor who needs intervention by continued policy. The key solution is in the business actors should be consistent with the established policy. This policy has gone through a long process through discussions with hearings between the provincial government and the coal businesses. This is proven by the tolerance period of one year given the provincial government to businessmen to make a special road. Giving deadlines in a policy can be interpreted as a policy problem solving. However, it does not automatically release the responsibility of local governments about coal transportation. The provincial government cannot wash its hands and return it to the district government authority. The relationship between the provincial government and district / city is not a relationship that is autonomous and independent of each other so it should always be in a unity of government function. The provincial government still running role as the central government representative in province area that has the authority of coordination, guidance, and supervision.

\section{Conclusion}

Based on discussion above, the author can formulate some conclusions, among others:

- The complexity of the coal transportation problems in Jambi province visible from some phenomenon, such as violation of rules by coal businessmen that still using public roads, demonstration of coal truck driver, residents protest by road blockade, and businessmen efforts to review local regulations (Perda and Pergub) to the court.

- The main problem is the difference in views between local governments and coal businesses. Disputes occurred at two levels, between Timdu with coal driver; and between citizens with coal driver. Beyond that, the coal truck driver becomes an instrument of coal businessmen to conduct response disobedience and resistance to local government policies.

Policy issues that have occurred can be parsed once we know the main point in relations between actors that need to be intervened by additional policy. The key to the solution is the coal entrepreneur must consistently adhere to the established policy. In addition, it should be underlined that in local governance, it takes the relationship between levels of government (intergovernmental relations) that is harmonious and conducive so that it can support the functions of government. If there is good coordination, implementation of the regulation, development, empowerment and public services will be more systematic, integrated, synchronized and do not overlap. Thus, it is clear that there is a close link between the provincial government and district/city governments concerning the regulation of coal transportation, in particular, the granting of licenses and the determination of the roads are passable. Policies issued by the provincial government cannot be effective if there is a policy vacuum at the district/city. If there are synergies among regional administrations on the matter, this problem can be resolved well as the rules and the system becomes clearer. So that law enforcement will be able to be done is supported by a complete and comprehensive regulation. With the synergy of horizontal and vertical coordination were adequate, the private sector and the public no longer multiple interpretations on coal transportation policy in Jambi province.

Recommendations: Based on conclusion, there are several recommendations as follows:

- Local government, coal businessman, and society representatives need to take a time for negotiation meeting to make commitment more clearly regarding coal transportation in Jambi province. 
- The coal businessmen as the law object must obey regulations that have been enacted. Provincial regulations should be supported by the district regulations in order to be applied consistently. Law enforcement is the key to solving some coal transportation problems.

- The provincial government should encourage the establishment of the cooperation forum among districts that related to the management of coal transportation. It is important to do because each of these regions also received the results of coal as a source of local revenue.

\section{References}

Bevir, M. (2007). The Encyclopedia of Governance. California: Sage Publication.

Dinas ESDM. (2011). Produksi Batubara Provinsi Jambi. Telanaipura: Pemerintah Provinsi Jambi.

Enroth, H. (2011). Policy Network Theory, in Bevir, M. (ed.). The SAGE Handbook of Governance. London: Sage Publication.

Jambi Independent. 15/1/2014, 20/1/2014, 12/3/2014. Daily Newspaper.

ESDM, Department. (2004). Peta Potensi Energi di Indonesia. Jakarta: ESDM RI.

Kickert, W. J. M., Klijn, E. H. \& Koppenjan, J. F. M. (1997). Managing Complex Networks: Strategies for the Public Sector. London: Sage Publication.

Klijn, E. H. \& Koppenjan, J. F. M. (2016).Governance Networks in the Public Sector. New York: Routledge.

Kozan, L. (2012). A demand-responsive decision support system for coal transportation. Decision Support Systems, 54, 665-680.

March, J. G. \& Olson, J. P. (1989). Rediscovering Institutions. The Organizational Basis of Politics. New York: Free Press.

Morrison, M. B. (1985). Transportation of US Western Coal: The impact of deregulation on unit train rates. Energy Policy, 3, 243-252.

Ostrom, E. (1990). Governing the Commons: The Evolution of Institutions for Collective Action. Cambridge: Cambridge University Press.

Satar, N. M. \& People, J. (2010). An empirical test of modal choice and allocative efficiency: Evidencefrom US coal transportation. Transportation Research, 46, 1043-1056. 